\title{
Perspective Of Stakeholders On The Sustainability Of Tuberkulosis Program
}

\author{
Indasah*, Dedi Saifulah, Anita Restu Korbaffo \\ Institut Ilmu Kesehatan STRADA Indonesia, Kediri \\ indasah.strada@gmail.com
}

\begin{abstract}
The threat faced in the sustainability of TB control programs is funding stability amid the high burden of TB cases in the community. The discovery of new TB cases The condition is exacerbated by the increase in cases of TB patients who are resistant to drugs that are increasingly complex and require a long time and medical expenses. This research is a type of descriptive research using a qualitative approach design using a case study research design. Funding for the TB program in Pasuruan Regency was sourced from the APBD and also Health Operational Assistance sourced from the Special Allocation Fund decreased. The budget for TB prevention prevention programs is absorbed entirely But the performance of achieving the discovery targets is still not significant. Still not found the whole case, complete treatment has not been maximized, some even DO. TB control activities allocated for TB prevention and control services appear to be relatively small compared to the TB treatment budget. Based on all the challenges faced, a strategy was formulated to eliminate TB within the next 5 years by strengthening the leadership of a quality TB service program with a sustainable program across stakeholders.
\end{abstract}

Keywords : Program, Strategic, Tuberculosis 


\section{STRADA Jurnal Ilmiah Kesehatan}

DOI: $10.30994 /$ sjik.v9i1.280

ISSN: 2252-3847 (print); 2614-350X (online)

Vol.9 No.1. May 2020. Page.224-240

\section{INTRODUCTION}

Indonesia currently faces a significant challenge with a burden of 660 / 100,000 population prevalence. The national TB control program continues to intensify, accelerate, extend, and innovate programs to deal with this situation. Indonesia even ranked third as the country with the highest TB burden in the world after India and China. (Umiasih \& Handayani, 2017). Based on TB report data in 2018, it is estimated that TB incidence in Indonesia in 2017 will be 842,000 cases ( $8 \%$ of the global TB incident burden) with annual TB deaths of 107,000 people (40 per 100,000 population) (WHO, 2018).

(Noveyani \& Martini, 2014) The TB Control Program from year to year shows quite good results, this can be seen from the increase in case detection rate (CDR) indicators from the CDR rate in 2003 which was only $37.6 \%$ to $77 \%$ in 2015 . The success rate of treatment in 2015 reached $89.7 \%$ which exceeded the MDG target of $85 \%$. In order to welcome the implementation of Sustainable Development Goals (SDGs), one of the aims of which is to ensure good health and well-being, the National Action Plan for TB Control 2015-2019 has been prepared. National action plans need to be followed and elaborated in accordance with local conditions, each of which remains a Regional Action Plan.

(Setiawan et al., 2016) Future TB control programs will greatly require funding sources from the central government, especially the regions, in accordance with the spirit of decentralization. To get commitment and support from all stakeholders requires strategic and planned efforts or processes. Advocacy is carried out to ensure commitment, better leadership, coordination and large investments from governments at all levels, from the central level to the district / city level, with the full involvement of the Ministry of Health and other key Ministries, including the Ministry of Finance, Ministry of Home Affairs, Ministry of Social Affairs, The Ministry of Environment, the Ministry of Public Works and Public Housing and other ministries.

The threat faced in the continuation of TB control programs is funding stability amid the high burden of TB cases in the community. The funding source for the TB control program that has been running so far is from the government and international donor agencies. The Global Fund for AIDS, Tuberculosis and Malaria (GF-ATM) is an international donor that has contributed greatly to TB program funding in Indonesia since 2002. The inclusion of Indonesia as an Upper Lower Middle Income Countries country is no longer the top priority country for international donor assistance (Kemenkes, 2012 ). The question that often arises is about how the sustainability of the program after external funding ends (Scheirer MA, 2011).

The discovery of new TB cases in districts / cities in 2018 were 2,728 cases. The number of cases in 2015 was 2,929 and for the cases found only 1,693 this figure had increased compared to previous years namely 977 in 2014 and 1,062 in 2013. The condition was made worse by the increase in cases of TB resistant people who were resistant to increasingly complex drugs requiring a long time and medical expenses. Drug-resistant TB reaches 100 times the cost of regular TB treatment and so far the amount of the treatment costs is the government's responsibility. The cost of treatment prepared by the government for one TBC patient resistant to medication until recovery requires $\mathrm{Rp}$. 100,000,000 up to Rp.150,000,000.

The 2013-2014 national TB prevalence survey (SPN) estimates the prevalence of tuberculosis at $660 / 100,000$, meaning that the current estimated TB in the community is 660 patients out of 100,000 population, while the prevalence in East Java Province is 316 / 100,000 population. The results of the provincial level evaluation put the District / city in 


\section{STRADA Jurnal Ilmiah Kesehatan}

DOI: $10.30994 /$ sjik.v9i1.280

the quadrant position of the district group that has good treatment outcomes but with a lack of case finding. This position emphasizes that the problem of controlling and controlling tuberculosis in very much requires serious and ongoing efforts (Program et al., 2015).

The problem of controlling TB RO needs to get extra attention from the local government and stakeholders. Treatment for TB RO requires a longer treatment period, heavier side effects and treatment funding reaches nearly 100 times the budget compared to regular TB treatment (Ministry of Health of the Republic of Indonesia, 2011).

The source of budget support for the TB control program comes from the GF ATM TB and KNCV donor APBD.

Regional Action Plan (RAD) for Tuberculosis Control based on Permenkes No. 43 of 2016 concerning SPM Health Sector and in line with this the Governor of East Java also issued letter number 440/16434/031/2016 concerning the Formulation of RAD TB. This RAD is a strategic reference for all government, private and community sectors in order to support the acceleration of TB elimination in 2035. Based on preliminary information / interviews with one of the stakeholders the Health Office stated that RAD is part of an exit strategy that guarantees a funding budget for TB control from various cross sectors, cross programs and non-governmental organizations (NGOs) so that the preparation involves many parties or stakeholders. The informant also expressed concern about RAD being only used as a document because the implementation of RAD evaluations that should be carried out annually to assess performance measurements is not yet running because a team has not been formed to function as an evaluator for the strategy. Another threat is related to funding stability because in $2018 \mathrm{~TB}$ program budget planning has been reduced more than 5 times compared to the previous year. This is because the 2018 budget is prioritized for P2P programs. Research in Ghana South Africa in 2013 proves that the results of a positive perspective from stakeholders are able to manage opportunities and threats that arise positively so that it can create a policy and planning strategy that is able to maintain and improve the progress of TB program achievements that have been achieved (Amo-Adjei J, 2013). This is the background of the importance of knowing how the perspectives of stakeholders towards the sustainability of TB programs. Desired description is how the stakeholder views about TB program sustainability by identifying strategic issues, opportunities and threats, especially related to the stability of TB Program funding and health financing strategies in securing new resources for the sustainability of TB prevention programs.

\section{METHODS}

\section{Research design}

This research is a type of descriptive study using a qualitative approach design using a case study research design. So that researchers will describe the whole by analyzing the thoughts, commitments and good attitudes obtained when taking interview data, as well as documentation about stakeholder perspectives on TB program sustainability capacity. Data collection methods with in-depth interviews as primary data and related report results as secondary data.

Data analysis techniques in this study consisted of three parts, namely data reduction as the selection process, focusing on simplification, abstracting and transformation of rough data that emerged from written notes in the field. The next stage is the presentation of data, testing qualitative data used is in the form of a brief description and narrative text. The last stage is 


\section{STRADA Jurnal Ilmiah Kesehatan}

DOI: $10.30994 /$ sjik.v9i1.280

ISSN: 2252-3847 (print); 2614-350X (online)

Vol.9 No.1. May 2020. Page.224-240

drawing conclusions / verification, drawing conclusions by comparing the researcher's questions with the results of the study.

\section{Research subject}

The research population is policy makers, program managers, service providers and stakeholders who play a role in program sustainability. The subjects of this study were 21 people as respondents from the Legislature; Executives and partners consisting of Professional Organizations, GF, KNCV.

\section{RESULTS}

Stability of TB Program Funding The condition of funding trends for the TB Program based on interviews with several research informants stated that the source of funds from the APBD showed a decrease in the past year (2018). The perspective is optimistic about the stability of funding sourced from the APBD by looking at the trend of increasing budget allocations in the last three years.

In the annual implementation of the TB control policy, it is made clear in the Health Office Work Plan (RENJA) through programs and activities, namely in the prevention and control of infectious diseases and TB service and prevention activities. These programs and activities are carried out at the Department of Health in the Field of Disease Prevention and Control with funding sources derived from Revenue Sharing and Special Allocation Funds. Besides that TB control is also carried out by the Puskesmas through a program of public health efforts through Health Operational Assistance with funds sourced from the Special Allocation Fund.

The existence of morbidity and mortality due to TB shows that efforts to control disease and environmental health are still not optimal. This issue is of particular concern in the Health Service Strategic Plan. So that the vision to be realized focus on "The realization of Health Service Governance for Community Welfare and Prosperity". Efforts to make this happen are by increasing health services that are evenly affordable and of high quality and also increasing the professionalism of health workers and developing management, health facilities and infrastructure.

Based on the evaluation of the implementation of the 2015 activity program specifically the TB prevention prevention program the budget provided was almost totally absorbed at $95.58 \%$. This shows that budget resources are fully utilized for efforts to eliminate TB. However, the performance of achieving the discovery target is still not significant. Because there is still no overall case, then the treatment has not been maximized because there are still those who have not undergone complete treatment, some even DO. According to the data mentioned to realize the repetition of TB cases then the program is arranged with a budget that has been determined as follows:

Table 4. Health Service Programs and Activities

\begin{tabular}{|c|c|}
\hline Programs / Activities & $\%$ \\
\hline Drug and Health Supplies Program & $40,12 \%$ \\
\hline Community Health Efforts Program & $56,61 \%$ \\
\hline Health Promotion and Community Empowerment Program & 76.51 \\
\hline Healthy Environment Development Program & 92.01 \\
\hline Infectious Disease Prevention and Management Program & 95.54 \\
\hline Disease Management Services Tb & $\mathbf{9 5 . 5 8}$ \\
\hline
\end{tabular}




\section{STRADA Jurnal Ilmiah Kesehatan}

DOI: $10.30994 /$ sjik.v9i1.280

If you look at the details in the table above it turns out that the percentage of TB financing is very small. The comparison description above shows that the TB control program is not enough to only be managed and financed sourced from the APBD for the Health Service alone. Budgeting through other DPOs related to TB control efforts also needs to be involved through community service programs that support TB prevention and control. Village funds originating from the APBN can also be used for activities that directly improve the ability of villages and their communities in TB control efforts.

Tuberculosis control activities in regencies / cities when viewed from the budget allocated for TB prevention and control services appear to be relatively small compared to the overall TB control budget (from various funding sources). This relatively small section budget is a TB program management budget and not a TB control operational budget. Whereas TB operational technical operational activities at the health service level are allocated in the BOK at each Puskesmas. For the procurement of TB drugs and other equipment budgeted through the Regency Pharmacy Installation (IFK). For the publication and promotion of TB prevention and prevention services budgeted through the Health Promotion Section. So the actual components for the same purpose are only grouped by budget groups.

The 2018 Incidence Rate is 472 / 100,000 population, based on this condition there are an estimated 7,630 TB cases that must be found while the realization of the findings reached 2,735 cases. The data shows that case finding efforts have not yet reached the target, so it is deemed necessary to accelerate efforts by the district government to eliminate TB by 2035 . The realization of performance in the last 4 years (2015 to 2018) is a database used to see trends in performance achievements. The performance indicators in the following table aim to determine the base line data used as the initial achievement conditions for calculating the gap against the target according to the year specified in the regional planning document (RPJMD and the Health Office Strategic Plan). The difference between the target and base line is a picture of the gap that must be resolved in the remaining period of time until the end of the RPJMD period and the Health Office Strategic Plan.

\section{Performance Indicator}

The TB performance indicators are inventoried for periods ranging from 2018 to 2022

Table 5. Performance Indicators for TB Control in 2018-2022

\begin{tabular}{|l|l|l|l|l|l|}
\hline \multicolumn{1}{|c|}{ Uraian } & \multicolumn{1}{c|}{$\mathbf{2 0 1 4}$} & \multicolumn{1}{c|}{$\mathbf{2 0 1 5}$} & \multicolumn{1}{c|}{$\mathbf{2 0 1 6}$} & \multicolumn{1}{c|}{$\mathbf{2 0 1 7}$} & \multicolumn{1}{c|}{} \\
\hline BTA pos new & 886 & 977 & 923 & 895 & 1277 \\
\hline BTA neg RO+ & 585 & 588 & 703 & 1079 & 1167 \\
\hline EP & 113 & 162 & 222 & 199 & 261 \\
\hline K-G-DO & 33 & 46 & 46 & 77 & 131 \\
\hline Children & 151 & 291 & 374 & 249 & 378 \\
\hline
\end{tabular}

An increase in the discovery of new cases in 2018 and a decrease in negative AFB rates. This means that the increase in new TB cases is not accompanied by the addition of patients who recover after undergoing treatment. So that more and more TB patients in 2018.

TB control performance in achieving

Elimination of TB in 2035 is carried out gradually and continuously. If it follows the national target, TB Elimination is expected to adjust to the achievement plan with the 5 year stages as follows:

a. In 2020 there was a decrease in morbidity due to TB by $30 \%$ and mortality by $40 \%$ compared to 2014 
b. In 2025 there was a decrease in morbidity due to TB by $50 \%$ and mortality by $70 \%$ compared to 2014

c. In 2030 there was a decrease in morbidity due to TB by $80 \%$ and mortality by $90 \%$ compared to 2014

d. In 2035 there was a decrease in morbidity due to TB by $90 \%$ and mortality by $95 \%$ compared to 2014

In the next 5 years the main performance target picture is as follows:

Table 6. Main Performance Targets

\begin{tabular}{|c|c|c|c|c|c|c|c|}
\hline \multirow{2}{*}{ No } & & \multirow{2}{*}{$\begin{array}{l}\text { Baseline } \\
\text { (2018) }\end{array}$} & \multicolumn{5}{|c|}{ Target } \\
\hline & & & 2018 & 2019 & 2020 & 2021 & 2022 \\
\hline \multicolumn{8}{|c|}{$\begin{array}{l}\text { STRATEGY 2. INCREASING ACCESS TO TB SERVICES WHICH IS QUALITY } \\
\text { WITH TOSS TB }\end{array}$} \\
\hline 1 & $\begin{array}{l}\text { Coverage of treatment of all } \\
\text { treated TB cases (case } \\
\text { detection rate/CDR) }\end{array}$ & $58 \%$ & $70 \%$ & $75 \%$ & $88 \%$ & & \\
\hline 2 & $\begin{array}{l}\text { Notification rates of all TB } \\
\text { cases treated (case } \\
\text { notification rate / CNR) per } \\
100,000 * \text { population }\end{array}$ & & 204 & 206 & 226 & & \\
\hline 3 & $\begin{array}{l}\text { The number of all TB cases } \\
\text { found and treated }\end{array}$ & 2735 & 3290 & 3722 & 3777 & & \\
\hline 4 & $\begin{array}{l}\text { Success rates for the } \\
\text { treatment of TB patients in } \\
\text { all cases }\end{array}$ & $90 \%$ & $90 \%$ & $90 \%$ & $90 \%$ & $90 \%$ & $90 \%$ \\
\hline 5 & $\begin{array}{l}\text { Percentage of TB re- } \\
\text { treatment cases that were } \\
\text { examined for drug } \\
\text { sensitivity testing by rapid } \\
\text { molecular testing or } \\
\text { conventional methods }\end{array}$ & $100 \%$ & $100 \%$ & $100 \%$ & $100 \%$ & $100 \%$ & $100 \%$ \\
\hline 6 & $\begin{array}{l}\text { Percentage of confirmed } \\
\text { drug resistant } \mathrm{TB} \text { cases }\end{array}$ & $100 \%$ & $40 \%$ & $60 \%$ & $70 \%$ & $80 \%$ & $80 \%$ \\
\hline 7 & $\begin{array}{l}\text { Percentage of drug resistant } \\
\text { TB cases that started } \\
\text { second-line treatment }\end{array}$ & $\begin{array}{c}85,71 \% \\
(24)\end{array}$ & $100 \%$ & $100 \%$ & $100 \%$ & $100 \%$ & $100 \%$ \\
\hline 8 & $\begin{array}{l}\text { Success rates for treatment } \\
\text { of drug resistant TB patients }\end{array}$ & $\begin{array}{l}60 \% \\
\text { (3) year } \\
2017\end{array}$ & $70 \%$ & $70 \%$ & $75 \%$ & $75 \%$ & $75 \%$ \\
\hline 9 & $\begin{array}{l}\text { Percentage of TB patients } \\
\text { who know their HIV status }\end{array}$ & $81,35 \%$ & $50 \%$ & $60 \%$ & $75 \%$ & $\%$ & $\%$ \\
\hline 10 & $\begin{array}{l}\text { Percentage of TB-HIV } \\
\text { patients getting PPK during } \\
\text { TB treatment }\end{array}$ & $\begin{array}{c}47,67 \% \\
(41)\end{array}$ & $100 \%$ & $100 \%$ & $100 \%$ & $100 \%$ & $100 \%$ \\
\hline 11 & $\begin{array}{l}\text { Percentage of TB-HIV } \\
\text { patients who received ARVs } \\
\text { during TB treatment }\end{array}$ & $\begin{array}{c}41,86 \% \\
(36)\end{array}$ & $100 \%$ & $100 \%$ & $100 \%$ & $100 \%$ & $100 \%$ \\
\hline
\end{tabular}




\begin{tabular}{|c|c|c|c|c|c|c|c|}
\hline & & \multirow{2}{*}{$\begin{array}{c}\text { Baseline } \\
\text { (2018) }\end{array}$} & \multicolumn{5}{|c|}{ Target } \\
\hline No & & & 2018 & 2019 & 2020 & 2021 & 2022 \\
\hline 12 & $\begin{array}{l}\text { Coverage of microscopic } \\
\text { laboratories participating in } \\
\text { cross tests at least } 3 \text { times in } \\
1 \text { year }\end{array}$ & $75 \%$ & $70 \%$ & $80 \%$ & $90 \%$ & - & \\
\hline 13 & $\begin{array}{l}\text { Percentage of microscopic } \\
\text { laboratories following } \\
\text { cross-tests with good results }\end{array}$ & $91 \%$ & $80 \%$ & $100 \%$ & $100 \%$ & $100 \%$ & $100 \%$ \\
\hline \multirow[t]{2}{*}{14} & $\begin{array}{l}\text { Coverage of TB case } \\
\text { finding in children }\end{array}$ & 364 & 567 & 539 & 503 & & \\
\hline & \multicolumn{7}{|c|}{ STRATEGY 3. RISK FACTOR CONTROL } \\
\hline 1 & $\begin{array}{l}\text { Percentage of children }<5 \\
\text { years who received } \\
\text { preventive treatment } \\
\text { compared to estimates of } \\
\text { children }<5 \text { years who were } \\
\text { eligible for preventive } \\
\text { treatment }\end{array}$ & 34 & 248 & 308 & 341 & & \\
\hline \multicolumn{8}{|c|}{$\begin{array}{l}\text { STRATEGY 5. INCREASING COMMUNITY INDEPENDENCE } \\
\text { IN TB CONTROL }\end{array}$} \\
\hline 1 & $\begin{array}{l}\text { Percentage of TB cases } \\
\text { found and referred by the } \\
\text { community or community } \\
\text { organizations (active case } \\
\text { finding) }\end{array}$ & $\begin{array}{c}2,30 \% \\
(65)\end{array}$ & $12 \%$ & $16 \%$ & $20 \%$ & $20 \%$ & $20 \%$ \\
\hline
\end{tabular}

\section{Strategic Issues}

This problem analysis utilizes data and information in summary of existing conditions to find the cause, inhibiting factors and their supporters. So that conclusions are drawn for the formulation of Strategic Issues. (Ministry of Health Republic of Indonesia, 2017) In the preparation of the Regional Action Plan (RAD) document for TB Control broadly refers to the National Strategy for TB Control and the National Action Plan (RAN) for TB Control in Indonesia. The process of formulating strategic issues is classified into 6 major groups of issues which can be elaborated in more detail according to efforts made in the field. The classification of strategic issues is intended to facilitate the preparation of Programs and Activities.

A. Commitment to the TB Program

Implementation of integrated TB control programs across sectors has not been running optimally, in general they are still carried out by the health department. Although the relevant OPD in the scope of the Government has planned and budgeted TB program support activities, the intensive coordination and communication process through the SKPD coordination forum and referring to the focused planning document has not yet been carried out.

On the other hand non-technical activities such as community empowerment to get to know TB disease and its anticipation have not been carried out by partner / non- 


\section{STRADA Jurnal Ilmiah Kesehatan}

DOI: $10.30994 /$ sjik.v9i1.280

government institutions. Meanwhile other regional apparatuses related to the management of health services for TB sufferers and the community still do not provide a significant budget for TB control activities. Other possible sources of funding can be directed to support TB control programs, among others, from the Village Fund, CSR and partner institutions, both local and donor agencies.

Basically, every OPD related to the implementation of the program and its activities always refers to the efforts to achieve the Vision in the RPJMD, however the results of the monitoring and evaluation process have not yet demonstrated the synergy of the programs between OPDs. Thus it can be concluded that the strategic issue regarding district commitment is the lack of TB program support in other related OPDs (Anggraini \& Mahendradhata, 2019).

Moreover, there is no Regional Regulation as a guideline for the implementation of integrated TB management and management including the planning and budgeting of the program.

From these problems there are strategies that can be done to solve the problem, namely by Strengthening the TB Program Leadership, which is with the support of the TB program from year to year in other DPOs that are felt to be less than optimal. In line with regional autonomy at the district / city level, intensive and well-coordinated advocacy activities are needed to ensure political commitment at the district level so that TB control becomes a priority program in the regions. This commitment should be supported by policies that are prepared specifically according to the situation and condition of the region. These include the existing rules and regulations, as well as the District Regulations on TB Control.

The aim is to increase regional leadership so that ownership, political commitment and awareness of the TB Prevention Program are formed in the form of regulations and to increase sustainable regional budget allocations. Program Description:

a. Establish TB as a Priority Program;

b. Formulation of Regional Government Policy

B. Improving Access to Quality "TOSS-TB" Services

1. Case Discovery

The management of TB patients using the DOTS strategy includes discovery and treatment efforts (Faradis \& Indarjo, 2018). Patient discovery is the first and foremost activity in TB control programs, by finding all smear positive pulmonary TB patients (infectious), with due regard to the discovery of other TB patients. Patient discovery activities comprise suspected screening, establishing TB diagnoses and determining disease classification and types of TB patients. The discovery and cure of infectious TB patients will have a significant impact in reducing morbidity and mortality due to $\mathrm{TB}$ and is the most effective effort to break the chain of TB transmission in the community. TB case finding is reviewed from several aspects, namely:

a. The aspects of Fasyankes consisting of Puskesmas, RSUD, Private hospitals, Private clinics, Independent practice doctors (DPM), Pesantren health posts that have the following obstacles:

- TB suspect screening conducted by providers is still tight so that the number of suspected TB investigators is low, this affects the TB case finding. 
- Suspect TB sufferers with negative smear examination results will require a diagnostic examination to support the diagnosis of pulmonary chest radiograph or X-ray used to support TB diagnosis. There are several problems in diagnosing tuberculosis diagnoses with chest X-ray / $\mathrm{x}$-ray photos including: all patients who need pulmonary thoracic / $\mathrm{x}$-ray images that do not have BPJS Health will require additional costs so that it becomes an additional burden for the patient, from this problem there will be many TB suspects who may not seek treatment continue TB examination. Utilization of TCM engine functions is not optimal at 2 TCM sites. Not all DPMs implement the recording and reporting system using standard standards (TB06, TB05, TB04, TB01, TB02 and case referrals / TB09 and TB10) so the findings are still low.

b. The aspects of society that sufferers, sufferers' families and members of the general public have constraints:

- Public knowledge is still low about information on signs and symptoms of tuberculosis so that people with symptomatic TB still access drugs independently to drugstores, pharmacies or to DPM services who have not implemented the DOTS strategy.

- OAT access without standard DOTS at the Pharmacy makes it easy for the community in non-standardized therapy so that records and findings cannot be recorded properly and properly through TB07 in health services, and can even lead to drug resistance.

- Patients have postponed starting treatment and there is no policy that requires patients to immediately seek treatment and sanctions if they do not start treatment immediately.

c. Aspects of supporting community organizations

Active case finding through community participation / CSOs has not been maximized. The biggest obstacle is mainly in sending suspects or specimens to health facilities. There is no Village Medicine Post that can bring the drug and PMO collection places closer by cadres.

d. Aspects of vulnerable groups / comorbidities consisting of: Nursing homes and shelters, TB for Children, Pregnant Women, TB-DM, Migrant Workers and Industrial Sector Workers and Pilgrims and Umrah pilgrims who still have obstacles include:

- Screening in nursing homes, elderly Posyandu and shelter has not been carried out;

- Investigation of contacts is still a priority for household contacts, while close contacts or those in the same primary environment at school (between teacher and student) at work (company) are under-emphasized;

- Contact investigation in pediatric TB cases in hospitals has not been maximized

- There are obstacles in the flow of screening with X-rays, related to BPJS financing;

- Not all pregnant women have TB screening, midwives have not all had midwives screening TB for pregnant women;

- TB screening at the Posyandu Elderly has not yet been carried out;

- Coordination with the Disnaker / Disperinda for screening workers 


\section{STRADA Jurnal Ilmiah Kesehatan}

DOI: $10.30994 /$ sjik.v9i1.280

- The management and implementation of TB programs for workers have not been maximized;

- Hajj and Umrah pilgrimage screening has not been done optimally;

○ TB screening in people with DM is still not optimal;

2. Treatment success

(Kurniawati et al., 2019) TB treatment aims to cure patients, prevent death or adverse effects caused, prevent recurrence, break the chain of transmission, prevent immunity to OAT and reduce social and economic impacts.

In terms of the success of TB treatment in East Java Province, the Regency / City ranks 13th out of 38 districts or cities. The success rate of treatment reached $91 \%$, this figure is above the average achievement in East Java Province in 2016 which was $86 \%$, and the National TB Control Target of $85 \%$.

Treatment of TB patients using the DOTS strategy is a continuing effort from the discovery of suspected tuberculosis. Patient discovery is the first and foremost step in the TB control program. Even though the achievement of the success of TB treatment in the Regency / City shows a pretty good number, problems are still found in the service providers and the community receiving the services. Here is the problem:

a. The untreated comorbidities and treatment ESOs aggravate the condition of TB patients, leading to low treatment success

b. The IEC material has not been effective and the ability of the medication adherence counseling officer is still lacking

c. Monitoring of loss to follow-up and transfer patients is not optimal

3. Drug-resistant TB

The discovery of TB RO patients is a series of activities that begin with the discovery of suspected TB RO and continue with the process of diagnosing TB RO diagnosis and supported efforts to prevent transmission to others. The discovery of TB RO patients will have a significant impact in reducing morbidity and mortality due to TB. In carrying out its role the TB program manager in a referral and sub-referral health facility needs to know, understand and carry out procedures for finding TB RO patients and enforce TBRO diagnoses properly. The current strategic issue of TB drug resistance is the low number of TB RO findings and treatments. Facts of the problems found in the field are:

a. The role of RSUD as MTPTRO service is not yet optimal

b. There has been no involvement of private health facilities, internal medicine doctors, and DPM in the discovery of RO patients

c. TB-RO patients refused treatment and several other patients dropped out due to side effects (ESO) and psychosocial economic factors (community stigma)

4. HIV TB

The diagnosis of pulmonary TB in people with HIV / AIDS (PLWHA) is no different from non-PLWHA. Establishing a diagnosis of TB in PLWHA is more difficult because PLWHA are difficult to sputum and cases of extra pulmonary TB often occur. At present the enforcement of TB-HIV diagnoses is carried out by government hospitals, several private hospitals and Puskesmas implementing VCT. Activities that can be served in addition to access to TB-HIV enforcement also access to ARVs (Faradis \& Indarjo, 2018). 
The percentage of TB patients who know their HIV status is still very small, this is due to the fact that there are still many TB officers who have not implemented PITC or Voluntary Counseling and Testing (KTS / VCT). TB screening in HIV patients is still less than optimal at the ARV initiation service.

Latent TB will appear in people with HIV and DM or other diseases that decrease immunity. In the context of finding TB cases with various co-infections and comorbidities with other diseases, efforts need to be improved both in terms of staff competencies and in accessing services and the readiness of the service itself. In this case a strategic issue for TB-HIV is the limited psychosocial support for TB-HIV patients because the CSO / NGO support is not optimal.

5. Laboratory Services

(Budi et al., 2018) The main enforcement of TB dysgnosis using sputum examination through smear staining and Molecular Rapid Test (TCM) is the main key that must be implemented by all public and private laboratories. The facts found show that the enforcement function by this laboratory has not contributed significantly to the case finding. Analysis of problems in laboratory services as follows:

a. not all laboratories are capable, able and trained in standard Tuberculosis examinations.

b. not all TB testing laboratories are trained and certified.

c. laboratory staff have not all attended TB laboratory training

d. limited number of Molecular Rapid Test machines (TCM) in accelerating access to diagnostics

e. SITRUS continuity after 2020

f. there is no MoU or network between government and private labs in the referral flow and TB examiner laboratories.

6. Patients' Houses are Uninhabitable

The importance of a healthy home for TB patients can minimize the transmission that can lead to new TB cases or possibly TB reinfection. The need for healthy homes for TB patients in regencies / cities has not been monitored, handled and coordinated with relevant parties.

7. Patient Transport Assistance

Issues related to transportation costs for TB patients is that there is no transport assistance for TB SO patients. In addition, continuity of transport assistance for patients with TB RO after 2020

8. Companion to Take Medication

TB treatment will cure most patients without triggering the emergence of drug resistant (immune) germs by means of the patient taking all the drugs given as directed by direct supervision by the PMO. Analysis of problems that occur in districts / cities, i.e

a. the role of PMO has not been maximized, especially in the case of DO

b. PMO HR trained for TB RO companion is still very limited

c. The absence of Village Drug Posts (POD)

From these problems the discovery of TB patients requires quality TB diagnosis services and is easily accessible. The diagnosis of TB is made through laboratory tests supporting the diagnosis using:

a. Microscopic examination; 

b. inspection with TCM;
c. other investigations such as chest X-ray and histopathology.
d. drug sensitivity test.

With the aim of: Improving access to services so that they can quickly find and treat TB patients until they recover through quality TB services. Program Description:
a. intensification of case finding in Public Health Centers and Hospitals;
b. extensification of case findings in private hospitals;
c. DPM involvement in TB control;
d. implementation of mandatory notifications for health facilities;
e. increased participation of private clinics in TB programs;
f. intensification of case finding in prisons'
g. increasing the role of Islamic boarding schools in TB case finding;
h. TB financing collaboration by BPJS;
i. increased contact investigation;
j. optimization of TB screening for pregnant women, elderly and children;
k. development of specific local IEC materials;
1. loss of follow-up and transfer patients monitoring;
m. improved test sample transportation systems;
n. optimization of investigative contacts;
o. treatment decentralization at the Puskesmas and village level;
p. expansion and addition of HIV testing service and HR facilities;
q. increasing collaborative programs and monitoring and evaluating TB-HIV;
r. optimization of laboratory governance;
s. fulfillment of infrastructure, equipment and human resources requirements in hospitals.

\section{Control of Risk Factors}

Risk prevention and control aims to reduce to eliminate transmission and incidence of TB disease in the community. Preventing TB transmission to all people involved in providing services to TB patients must be a major concern. All facilities that provide TB services must implement TB Prevention and Control (PPI) to ensure immediate detection, prevention and treatment of someone suspected or confirmed to have TB. There are 3 strategic issues about controlling risk factors, namely:

1. Promotion of environmental health and PHBS related to TB has not been optimal;

2. The implementation of PPI TB in health facilities and other than health facilities has not yet been carried out

3. Not yet socialized the prevention and treatment of TB in PLWHA Children and people at risk

The risk of becoming ill with TB increases in children aged $<5$ years, young adults, pregnant women, the elderly, PLWHA, people with DM, malnutrition, immunosuppressive conditions, and unhealthy life behaviors such as smoking (risk of getting pulmonary TB as much as 2, 2 times).

With the aim of: Reducing the transmission and incidence of TB sickness by making efforts to prevent TB transmission in the community and in health facilities. Program description:

1. promotion of PHBS and TB; 


\section{STRADA Jurnal Ilmiah Kesehatan}

DOI: $10.30994 /$ sjik.v9i1.280

2. prevention and control of TB infection in health service facilities and special places;

3. BCG vaccination;

4. increasing the capacity of health workers in providing PPINH.

D. Strengthening TB Program Partnerships

In the implementation of TB control programs that involve partnership support the issue is the TB service network is not functioning properly. The following problems were identified in the field:

1. Not yet coordinated the TB care group

2. TB is not yet an input in CSR activities

3. Mandatory reporting from DPM is not going well

4. The collaboration of specialist doctors supporting the TB program is still lacking

5. PPM activities are still not active

6. Network involvement with company clinics and Islamic boarding schools is still lacking

The TB Control Strategy requires active participation from all relevant stakeholders and partners, bearing in mind the magnitude of the problems and challenges faced by the current Program which include health technology issues, resources, leadership commitment requires governance that involves elements of partnership, because these problems are not just problems health is the main duty of the health department.

Preparation of NSPK TB Control Program requires input from partners so that the strategy is right on target and can be implemented. TB program partners that must be involved are Cross Sectoral and Cross Program Institutions, Health Professional Organizations, Higher Education, Social Health Organizations, Health financing Institutions, technical partners, donor partners, NGOs or social organizations and the private sector. The partnership was included in the TB Coordination Forum at the provincial and district or city levels. The forum is adapted to the local situation and conditions if it has been developed and functioning in the area. Program description:

1. increasing the capacity of the PPM team;

2. establishing TB coordination forums at sub-district level;

3. increasing the capacity of members of professional organizations in P2 TB;

4. cooperation between private pharmacies and DOTS health service facilities;

5. collaboration between the $\mathrm{DHO}$ and schools and colleges in $\mathrm{TB}$ service research and networking.

E. Strengthening Community Independence in TB Control

Strategic issues: lack of community independence in the P2PM program. The following analyzes the problem with the role of the community:

1. Unequal public understanding of TB disease

2. Not all cadres understand TBC

3. There is no community of former TB patients

4. There has been no strengthening of economic empowerment in former TB patients Based on the Regulation of the Minister of Health No. 65 of 2013 concerning Guidelines for the Implementation and Development of Community Empowerment in the Health Sector, it was explained that for the successful implementation of various efforts to empower the community in the health sector more focused on:

1. Increasing changes in behavior and community independence for PHBS 


\section{STRADA Jurnal Ilmiah Kesehatan}

DOI: $10.30994 /$ sjik.v9i1.280

2. increasing community independence in the early warning system, overcoming health impacts from disasters, as well as outbreaks / outbreaks;

3. increasing community integration in the health sector with activities that have an impact on income generation.

Through the expansion of TB control programs the Regency / city government has expanded community involvement. Problems with access, financing and infrastructure and human resources were overcome by starting community-based activities. The community plays a major role in monitoring drug use, tracking cases and finding suspects. The availability of information about TB is increased by increasing budget allocations for TB promotion.

Efforts to make the community independent are continued by strengthening the capacity of program managers at the district level, integrating TB services into UKBM and opening the horizons of TB patients by promoting the charter of TB Patients' Rights and Obligations. Improved coordination between local government and community organizations in promotion and empowerment is strengthened by the hope that those affected will be actively involved and empowered so that there will be changes in attitudes and behavior related to TB prevention and treatment.

For this reason promotion of promotion and empowerment needs to be done with the hope that those affected by both patients, former patients and the community will be actively involved and empowered so that they develop an independent attitude in TB prevention and treatment. Program description:

1. strengthening CSO capacity in managing TB programs;

2. improvement of CSO Resources (HR and funds);

3. Form a container of peer support.

F. Strengthening the Health System

There are 3 strategic issues in strengthening the health system, namely:

1. Health system

a. Not all health care workers have mastered the use of SITT

b. TB data collection system is not optimal

c. The contact investigation program is not optimal

d. Not yet connected SIRS (Hospital Information System) with data needed in SITT

e. Internal and external networks in health care facilities are still less than optimal

2. Procurement and Distribution of TB Logistics

a. The lack of IEC logistics and the ability of officers in suspicion enforcement, which causes the screening of suspected TBs in Puskesmas is still too tight

b. Lack of RR facilities (laptops), which causes TB recording and reporting systems in PKM have not run optimally

c. The comorbid treatment logistic is not yet available in FKTP services, causing the success of the treatment of TB patients with comorbid is not optimal

3. Increased HR Capacity

Lack of capacity building programs for Doctors, Paramedics, TB officers and service networks.

Strengthening Program Management through strengthening the health system component is very important in the national strategy for the TB Prevention Program. This strategy discusses action plans for improving services, human 


\section{STRADA Jurnal Ilmiah Kesehatan}

DOI: $10.30994 /$ sjik.v9i1.280

resources, logistics and strategic information systems, operational research and surveillance.

Patient's access to services must be as wide open as possible so that anyone who needs it can immediately get services according to their needs. Acceleration must be done with rapid expansion by increasing the number and type of services and improving its quality. I

Government and private health workers at all levels must have the knowledge, attitudes and competencies needed to be able to carry out and optimize activities including TB prevention, care and control, including efforts to improve HIV management and overcome barriers to TB RO services. Therefore it is necessary to have the number and type and quality of personnel needed and who are involved in implementing the program at all levels of the health system must be adequate. Program description:

1. strengthening TB surveillance in health care facilities through SITT;

2. strengthening TB data collection systems;

3. strengthening TB logistics management;

4. preparation of district level TB Trainer Teams;

5. increasing the capacity of health facilities officers;

6. increasing CSO capacity and the role of cadres for TB case finding;

7. Increasing the capacity of laboratory personnel in external quality testing.

\section{Financing}

In the context of health service delivery, financing is an absolute element that must be available. District / city government annually plans and establishes APBD as a guideline in regulating revenue and expenditure for the implementation of regional development. Its implementation is a follow-up to development planning which is endorsed by the executive and legislative branches. It contains the principal funding for realizing all development programs and activities, both in the form of direct expenditure, indirect expenditure and other financing.

Funding for activities in the TB Control RAD is basically the amount of investment planned to fund the implementation of TB prevention programs and activities based on identified needs.

The financing mechanism is carried out in accordance with the principles and conditions set by the regional government and other sources of funding. Funding from the APBD uses the annual budget calendar mechanism.

A. Financing Calculation Process

Each activity identified is generally an activity that will be carried out every year (multiyear). For this annual activity the process of calculating the financing is done once at the beginning of the preparation of the plan. Each activity contains information about the volume of activities consisting of variables, frequencies and units or units as a basis for calculation. Determination of the volume of activities is a separate process that must be done carefully by the RAD Formulation Team.

To simplify this calculation process, the regency / city government uses the Worksheet Format tool. In the process of calculating the funding for TB Control RAD activities, the use of Leker is adjusted according to Strategy 1 - 6 groups, this is intended to facilitate the reading and preparation of the Plan 


\section{CONCLUSION}

TB Program Funding The condition of funding trends for the TB Program based on interviews with several research informants stated that the source of funds from the APBD showed a decrease. TB control is also carried out by Puskesmas through community health efforts through Health Operational Assistance with funds sourced from the Special Allocation Fund.

The TB budget prevention program provided is almost completely absorbed. This shows that the budgetary resources are fully utilized to eliminate TB. However, the performance of achieving the discovery target is still not significant. Because there is still no overall case, then the treatment has not been maximized because there are still those who have not undergone complete treatment, some even DO. Tuberculosis control activities when viewed from the budget allocated for TB prevention and control services look relatively small compared to the overall TB control budget.

Based on all the challenges faced, a strategy was formulated to eliminate TB within the next 5 years. This strategy is expected to gradually reduce the burden of TB control. The formulation of the strategy is inseparable from the strategic framework according to the National Action Plan for TB Control in 2016 to 2020. With 6 strategies, namely strengthening TB program leadership, increasing access to quality TB services, controlling risk factors, increasing partnerships through TB coordination forums, increasing community independence in TB control and strengthening program management through strengthening the health system.

\section{REFERENCES}

Amo-Adjei J. (2013). Perspectives of Stakeholders on the Sustainability of Tuberculosis Control Programme in Ghana. http://www.hindawi.com/journals/ trt/2013/419385/

Anggraini, R. D., \& Mahendradhata, Y. (2019). Perspektif Stakeholder Terhadap Sustainability Program TB di Kota Semarang. Jurnal Kebijakan Kesehatan Indonesia : JKKI, 8(2), 95-101. https://doi.org/10.22146/JKKI.46502

Budi, I. S., Ardillah, Y., Sari, I. P., \& Septiawati, D. (2018). Analisis Faktor Risiko Kejadian penyakit Tuberculosis Bagi Masyarakat Daerah Kumuh Kota Palembang. Jurnal Kesehatan Lingkungan Indonesia, 17(2), 87. https://doi.org/10.14710/jkli.17.2.87-94

Faradis, N. A., \& Indarjo, S. (2018). Implementasi Kebijakan Permenkes Nomor 67 Tahun 2016 tentang Penanggulangan Tuberkulosis. HIGEIA (Journal of Public Health Research and Development), 2(2), 307-319. https://doi.org/10.15294/higeia.v2i2.21291

Kemenkes. (2012). Pedoman Exit Strategi Dana Hibah Global Found Aids, Tuberkulosis dan Malaria (pp. 1-46p).

Kementerian Kesehatan RI. (2011). Rencana Aksi Nasional Public Private Mix Tuberkulosis Indonesia : 2011-2014.

Kementerian Kesehatan RI. (2017). Petunjuk Penyusunan Rencana Aksi Daerah untuk Tuberkulosis.

Kurniawati, A., Mahendradhata, Y., \& Padmawati, R. S. (2019). Acceptability Notifikasi Wajib Tuberkulosis (TB) pada Dokter Praktik Mandiri dan Klinik Pratama Swasta di Kota Yogyakarta. Jurnal Kebijakan Kesehatan Indonesia: JKKI, 8(1), 1-9. https://doi.org/10.22146/JKKI.37426 
Noveyani, A. E., \& Martini, S. (2014). Evaluasi Program Pengendalian Tuberkulosis Paru Dengan Strategi DOTS Di Puskesmas Tanah Kalikedinding Surabaya. Jurnal Berkala Epidemiologi, 2(2), 251-262.

Program, D., Penyakit, P., \& Paru, T. B. (2015). Evaluasi Input Capaian Case Detection Rate (Cdr) Tb Paru Dalam Program Penanggulangan Penyakit Tb Paru (P2Tb) Puskesmas Tahun 2012 (Studi Kualitatif Di Kota Semarang). Unnes Journal of Public Health., 4(2), 143-152. https://doi.org/10.15294/ujph.v4i2.5191

Scheirer MA, D. J. (2011). An Agenda for Research on the Sustainability of Public Health Programs. Public Health, 10, 110. https://www.ncbi.nlm.nih.gov/pmc/ articles/PMC3222409/pdf/2059.pdf

Setiawan, E., Sucahya, P. K., Thabrany, H., \& Komaryani, K. (2016). A Comparative Budget Requirements for TB program based on Minimum standard of Services (SPM) and Budget Realization: an Exit Strategy Before Termination of GF ATM. Jurnal Ekonomi Kesehatan Indonesia, 1(1), 12-22. https://doi.org/10.7454/eki.v1i1.1761

Umiasih, S., \& Handayani, O. W. K. (2017). Peran Serta Kelompok Masyarakat Peduli Paru Sehat Dalam Program Pengendalian Penyakit Tuberkulosis. Higeia Journal of Public Health, 1(1), 1-7. http://journal.unnes.ac.id/sju/index.php/higeia

WHO. (2018). Global Tuberculosis Report 2017. 